\title{
Changes in Pulsatile Coronary Blood Flow Induced by Coronary Vasodilators
}

\author{
Yoshiro Nakamura, M.D., Hideki Nagoshi, M.D., \\ Fumio TAKeI, M.D., Bernward Schölkens, M.D., and \\ Hiroshi Sasamoto, M.D.
}

\section{SUMmary}

Nine mongrel dogs were sacrificed to know hemodynamic effect of nitroglycerin, dipyridamole and theophylline ethylendiamine on coronary circulation.

Coronary blood flow (CBF) was measured by electromagnetic flowmeter. Aortic and left ventricular pressure were measured at the same time. Arterial and coronary sinus oxygen tension were measured.

Dipyridamole gave effect of marked and continuous increase in CBF, decrease in coronary vascular resistance (CVR) and raised coronary sinus oxygen tension.

Nitroglycerin gave effect of increase in heart rate immediately after the injection, followed by decreased heart rate and decrease in TTI $3 \mathrm{~min}$. later.

Theophylline ethylendiamine gave effect of decreased CVR and TTI immediately after the injection, however, noteworthy change could not be seen 3 min. later.

The types of change in coronary vascular resistance induced by coronary vasodilators were divided into 3 groups.

In group A, decrease in systolic CVR without decrease in enddiastolic CVR (EDCVR) was seen. Here, decrease in TTI with increased heart rate was seen.

In group B, coronary vasodilation in enddiastole without decrease in mean CVR was seen. Probably, extravascular compression played an important role here.

In group $\mathrm{C}$, reduction of CVR in systole and enddiastole was seen with decrease in TTI/CBF ratio and lowered aortic pressure, suggesting extravascular compression was rather indifferent.

\section{Additional Indexing Words :}

Nitroglycerine Dipyridamole Theophylline ethylendiamine TTI TTI/CBF Enddiastolic coronary resistance Extravascular compression

TARIOUS kinds of studies ${ }^{1-6)}$ have been done referring to the effects of so called coronary vasodilators on cardiovascular system. Recent development of electromagnetic flow meter (EMF) has made it possible to record pulsatile coronary arterial blood flow. Several types of changes in flow pat-

From the Department of Medicine, School of Medicine, Keio University, Tokyo.

Received for publication February 4, 1970. 
tern accompanied with the increase in mean coronary blood flow (CBF) were found concerning the extravascular compression to coronary artery raised by myocardial contraction. ${ }^{\text {7)-9) }}$

This study was carried out under the intention of knowing the characteristic feature of hemodynamic changes caused by nitroglycerin (NTG), theophylline ethylendiamine (TED) and dipyridamole (DIP). This implied to make it clear whether changes in relationship between left ventricular work and mean $\mathrm{CBF}$ gave a certain effect on pulsatile $\mathrm{CBF}$ or not and also to know what difference could be seen in coronary blood flow pattern following the application of foregoing coronary vasodilators.

\section{Methods}

Successful experiments were performed in 9 mongrel dogs weighing $13-18 \mathrm{Kg}$. anesthetized by intravenous injection of pentobarbital $(25 \mathrm{mg} . / \mathrm{Kg}$. $)$. The chest was opened in the 5th intercostal space under the artificial respiration. The pericardium was incised and a square wave EMF (Nihon Koden MF5) was placed around the left circumflex artery. Ascending aortic blood pressure and left ventricular pressure were measured by Statham $\mathrm{P} 23 \mathrm{Db}$ pressure gauge connected with vinyle catheter through the femoral artery and the left atrial appendage respectively.

Recording and blood sampling were made $30 \mathrm{sec}$, $90 \mathrm{sec}$, and $3 \mathrm{~min}$. after the injection of coronary vasodilators into the inferior caval vein. Doses of DIP was $0.6-0.8 \mathrm{mg} . / \mathrm{Kg}$., that of N'G was $0.017-0.023 \mathrm{mg} . / \mathrm{Kg}$. and that of TED was $14-19.2 \mathrm{mg} . / \mathrm{Kg}$. When these drugs were used in series in the same dog, it was made sure that every tracing returned to control values $10 \mathrm{~min}$. before next manipulation. Recording was obtained by Visigraph (Sanei FR301) at the speed of $10 \mathrm{~cm} . / \mathrm{sec}$.

Blood samples for the measurement of $\mathrm{PO}_{2}, \mathrm{PCO}_{2}$ and $\mathrm{pH}$ were collected from the catheter inserted into the coronary sinus and the ascending aorta. Macroelectrode (IL meter) was used for these blood gas analyses.

After reaching steady state foregoing recording and blood sampling were done in order to obtain control values. Bolus injection of vasodilator was made in the inferior caval vein. DIP was used in the third place of the test substances, because its effects continued long time. Eleven observations were made on DIP, 12 on NTG and 8 on TED.

Calibration of flow probe was performed with cellophane tubing for the hemodialysis with normal saline. In order to obtain blood flow per beat, area surrounded by $\mathrm{CBF}$ pattern and zero line was calculated planimetrically. Enddiastolic coronary vascular resistance (EDCVR) ${ }^{7}$ ) was calculated by enddiastolic aortic pressure divided by the rate of enddiastolic coronary flow and expressed in a unit (mm.Hg/ml./min.). Mean coronary vascular resistance (MCVR) was calculated

EMF: Electromagnetic flow meter CBF: Coronary blood flow MCBF: Mean coronary blood flow NTG: Nitroglycerin TED: Theophylline ethylendiamine DIP: Dipyridamole CVR: Coronary vascular resistance MCVR: Mean coronary vascular resistance EDCVR: Enddiastolic coronary vascular resistance MAP: Mean aortic pressure $\mathrm{HR}$ : Heat rate $\mathrm{PcsO}_{2}$ : Coronary sinus oxygen tension. 
by mean aortic blood pressure divided by mean coronary blood flow.

As an index of left ventricular myocardial oxygen consumption, TTI (mm.Hg/ sec. $)^{10)}$ was used and the TTI/CBF ratio was thought to express oxygen demand and supply to the myocardium.

Statistical consideration was paid by having T-test and significance was shown at the risk of $0.05 \%$ of probabilities.

\section{RESULTS}

Hemodynamic changes $3 \mathrm{~min}$. after the injection of coronary vasodilators were compared with control values (Table I). Significant increase in CBF was found in DIP, while immediate increase was already found after the injection of NTG and TED.

Follow up study in time course revealed that $21.5 \%$ and $46.4 \%$ of increase in $\mathrm{MCBF}$ were seen 30 and $90 \mathrm{sec}$. after the injection of DIP respectively. $5.7 \%$ and $13.5 \%$ of increase in $\mathrm{MCBF}$ were seen 30 and $90 \mathrm{sec}$. after the injection of TED. Increase in mean $\mathrm{CBF}(\mathrm{MCBF})$ was found immediately after the injection of NTG, while it was not seen after $30 \mathrm{sec}$. No significant change in mean aortic pressure (MAP) was found $3 \mathrm{~min}$. after the injection of coronary vasodilators. However, $30 \mathrm{scc}$. after the injection of TED and NTG, $20 \%$ and $14.1 \%$ of decrease in MAP were seen respectively.

TED showed maximum increase in heart rate up to $21.7 \% 40 \mathrm{sec}$. after

Table I. Effects of Dipyridamole, Nitroglycerin and Theophylline Ethylendiamine on Hemodynamics 3 min. after the Injection

\begin{tabular}{|c|c|c|c|c|c|c|c|c|c|}
\hline & \multicolumn{3}{|c|}{ DIP } & \multicolumn{3}{|c|}{ NTG } & \multicolumn{3}{|c|}{ TED } \\
\hline & $\begin{array}{l}\text { Control } \\
\pm S D\end{array}$ & $\begin{array}{c}\text { Response } \\
\pm \mathrm{SD}\end{array}$ & $\mathbf{P}$ & $\begin{array}{c}\text { Control } \\
\pm \mathrm{SD}\end{array}$ & $\begin{array}{c}\text { Response } \\
\pm \mathrm{SD}\end{array}$ & $\mathrm{P}$ & $\begin{array}{l}\text { Control } \\
\pm \mathrm{SD}\end{array}$ & $\begin{array}{c}\text { Response } \\
\pm \mathrm{SD}\end{array}$ & $\mathbf{P}$ \\
\hline $\begin{array}{l}\text { Mean AP } \\
(\mathrm{mm} . \mathrm{Hg})\end{array}$ & $\begin{array}{l}107.7 \\
\pm 25.6\end{array}$ & $\begin{array}{l}104.3 \\
+21.0\end{array}$ & ns & $\begin{array}{l}116.3 \\
\pm 26.6\end{array}$ & $\begin{array}{l}105.2 \\
\pm 24.1\end{array}$ & ns & $\begin{array}{l}102.8 \\
\pm 19.8\end{array}$ & $\begin{array}{l}98.2 \\
+25.8\end{array}$ & ns \\
\hline $\begin{array}{l}\text { Mean CBF } \\
\left.(\mathrm{ml} / / \min )^{\prime}\right)\end{array}$ & $\begin{array}{l}69.2 \\
\pm 58.2\end{array}$ & $\begin{array}{l}98.2 \\
\pm 74.8\end{array}$ & $<0.02$ & $\begin{array}{l}58.1 \\
\pm 54.8\end{array}$ & $\begin{array}{l}56.5 \\
\pm 52.8\end{array}$ & ns & $\begin{array}{l}63.3 \\
\pm 61.6\end{array}$ & $\begin{array}{l}74.9 \\
\pm 72.2\end{array}$ & ns \\
\hline CVR (unit) & $\begin{array}{l}2.1 \\
\pm 1.2\end{array}$ & $\begin{array}{l}1.3 \\
\pm 0.7\end{array}$ & $<0.02$ & $\begin{array}{l}2.5 \\
\pm 1.5\end{array}$ & $\begin{array}{l}1.9 \\
\pm 1.1\end{array}$ & ns & $\begin{array}{l}2.1 \\
\pm 1.3\end{array}$ & $\begin{array}{l}1.6 \\
\pm 1.3\end{array}$ & ns \\
\hline $\begin{array}{l}\mathrm{HR} \\
\text { (beats/min.) }\end{array}$ & $\begin{array}{l}157.1 \\
\pm 30.6\end{array}$ & $\begin{array}{l}156.3 \\
\pm 34.1\end{array}$ & ns & $\begin{array}{l}162.1 \\
\pm 31.3\end{array}$ & $\begin{array}{l}156.7 \\
\pm 33.0\end{array}$ & $<0.05$ & $\begin{array}{l}145.1 \\
\pm 13.5\end{array}$ & $\begin{array}{l}171.8 \\
\pm 45.7\end{array}$ & $\mathrm{~ns}$ \\
\hline $\begin{array}{l}\text { TTI } \\
(\mathrm{mm} . \mathrm{Hg} \cdot \mathrm{sec} .)\end{array}$ & $\begin{array}{r}2,723.1 \\
\pm 421.2\end{array}$ & $\begin{array}{r}2,759.1 \\
\pm 406.7\end{array}$ & ns & $\begin{array}{r}2,835.0 \\
\pm 593.3\end{array}$ & $\begin{array}{r}2,532.5 \\
\pm 649.8\end{array}$ & $<0.05$ & $\begin{array}{r}2,496.0 \\
\pm 487.2\end{array}$ & $\begin{array}{r}2,498.8 \\
\pm 466.3\end{array}$ & ns \\
\hline $\mathrm{TTI} / \mathrm{CBF}$ & $\begin{array}{l}27.2 \\
\pm 4.1 \\
\end{array}$ & $\begin{array}{l}19.4 \\
\pm 6.9\end{array}$ & $<0.01$ & $\begin{array}{l}28.4 \\
\pm 5.9\end{array}$ & $\begin{array}{l}27.2 \\
+11.1\end{array}$ & ns & $\begin{array}{l}25.0 \\
\pm 4.7\end{array}$ & $\begin{array}{l}22.7 \\
\pm 7.0\end{array}$ & $\mathrm{~ns}$ \\
\hline $\begin{array}{l}\mathrm{PcsO}_{2} \\
(\mathrm{~mm} . \mathrm{Hg})\end{array}$ & $\begin{array}{l}20.6 \\
\pm 6.9\end{array}$ & $\begin{array}{l}26.2 \\
\pm 7.2\end{array}$ & $<0.05$ & $\begin{array}{l}23.3 \\
\pm 6.2\end{array}$ & $\begin{array}{l}24.2 \\
\pm 7.3\end{array}$ & $\mathrm{~ns}$ & $\begin{array}{l}25.8 \\
\pm 9.4\end{array}$ & $\begin{array}{l}24.8 \\
\pm 12.3\end{array}$ & $\mathrm{~ns}$ \\
\hline
\end{tabular}


the injection. Three min. after the injection of NTG, significant decrease in heart rate was found. Maximum increase in heart rate was found $30 \mathrm{sec}$. after the injection of DIP and NTG, DIP showed 5.4\% of increase and NTG showed $4.4 \%$ of increase.

Though DIP did not change TTI, TED and NTG decreased TTI at maximum degree $30 \mathrm{sec}$. after the injection. Here, TED showed $21.9 \%$ of decrease and NTG showed $13.5 \%$ of decrease. Three min. after the injection of TED, TTI returned to control value while it was still decreased $3 \mathrm{~min}$. after the injection of NTG.

Only DIP decreased significantly TTI/CBF ratio 3 min. after the injection accompanied with increase in coronary sinus oxygen tension $\left(\mathrm{PcsO}_{2}\right)$. Such tendencies could not be seen in other coronary vasodilators.

Three min. after the injection of DIP, EDCVR decreased significantly. In TED group $30 \mathrm{sec}$. after the injection, EDCVR decreased to $55.1 \%$ and $90 \mathrm{sec}$. after injection to $31.7 \%$. In NTG group EDCVR decreased to $22 \%$. Both of these drugs did not decrease EDCVR $3 \mathrm{~min}$. after the injection as statistics showed.

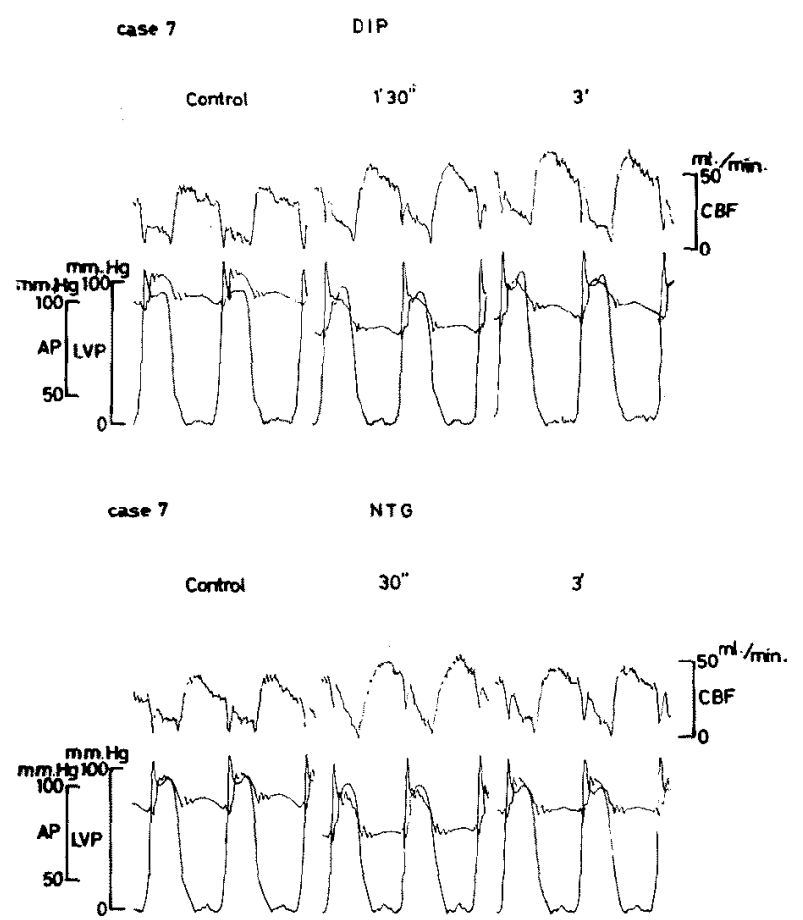

Fig. 1. The upper showed coronary blood flow pattern in which diastolic and systolic flow increased. The lower showed coronary blood flow pattern in which only diastolic CBF increased. 
Moment to moment distribution of CBF during cardiac cycle made it possible to divide the results into 2 groups. This is to say, in 1 group, both diastolic and systolic $\mathrm{CBF}$, in the other, only diastolic CBF was increased (Fig. 1). In former group, MCVR was considered to be decreased, while in some of the latter group, MCVR was unchanged.

Thus from foregoing viewpoint, 3 groups were made for convenience. They were called group A, B and C.

Table II. Number of the Cases of Group A, Group B and Group C Which Appeared in Time Course after the Injection of Coronary Vasodilators

\begin{tabular}{|c|c|c|c|c|c|}
\hline & & $30^{\prime \prime}$ & $1^{\prime} 30^{\prime \prime}$ & $3^{\prime}$ & Total \\
\hline \multirow{3}{*}{ A } & $\mathrm{D} I \mathrm{P}$ & 1 & 0 & 1 & 2 \\
\hline & NTG & 2 & 1 & 0 & 3 \\
\hline & T E D & 0 & 0 & 0 & 0 \\
\hline \multirow{3}{*}{ B } & $\mathrm{D} I \mathbf{P}$ & 1 & 0 & 0 & 1 \\
\hline & NTG & 1 & 1 & 2 & 4 \\
\hline & T E D & 0 & 0 & 3 & 3 \\
\hline \multirow{3}{*}{$\mathrm{C}$} & $D I P$ & 3 & 7 & 8 & 18 \\
\hline & NTG & 4 & 5 & 4 & 13 \\
\hline & $\mathrm{TED}$ & 5 & 6 & 4 & 15 \\
\hline
\end{tabular}

In group A, MCVR decreased and EDCVR increased or remained unchanged.

In group B, MCVR increased or remained unchanged and EDCVR decreased.

In group C, MCVR decreased and EDGVR decreased.

Here, decrease and increase were recognized with $10 \%$ change of control value. Cases in which changes could not be found over this level were eliminated from these data.

These data were summarized in Table II. Comparatively few number of the cases were included in group A. In group B, cases belonging to NTG and TED group occupied majority. Changes in GVR in group $\mathrm{C}$ were most frequently seen after the injection of all 3 coronary vasodilators.

MCBF, heart rate (HR), MAP and TTI were compared among foregoing groups (Table III).

Results obtained $3 \mathrm{~min}$. after the injection of coronary vasodilators were shown in Table IV. and the relationship coming from these results resembled that of Table III.

The foregoing phenomena could be summarized as follows: 
Table III. Changes in Mean CBF, HR, Mean AP and TTI Obtained in Group A, Group B and Group C after the Injection of

Coronary Vasodilators

\begin{tabular}{l|r|r|r|r|r|r|r|r|r}
\hline & \multicolumn{3}{|c|}{ A } & \multicolumn{3}{c|}{ B } & \multicolumn{3}{c}{ C } \\
\cline { 2 - 8 } & Control & After & $\mathrm{P}$ & Control & After & $\mathrm{P}$ & Control & After & $\mathrm{P}$ \\
\hline $\begin{array}{l}\text { Mean CBH } \\
\text { (ml./min.) }\end{array}$ & 57.2 & 63.6 & $\mathrm{~ns}$ & 43.7 & 49.6 & $\mathrm{~ns}$ & 57.3 & 80.4 & $<0.01$ \\
\hline $\begin{array}{l}\mathrm{HR} \\
\text { (beats/min.) }\end{array}$ & 163.8 & 171.4 & $<0.02$ & 156.4 & 160.5 & $\mathrm{~ns}$ & 157.8 & 168.1 & $<0.01$ \\
\hline $\begin{array}{l}\text { Mean AP } \\
\text { (mm.Hg) }\end{array}$ & 124.8 & 117.5 & $\mathrm{~ns}$ & 101.3 & 97.8 & $\mathrm{~ns}$ & 112.5 & 97.3 & $<0.01$ \\
\hline $\begin{array}{l}\text { TTI } \\
\text { (mm.Hg.sec.) }\end{array}$ & $3,460.0$ & $3,059.0$ & $<0.05$ & $2,408.3$ & $2,288.6$ & $\mathrm{~ns}$ & $2,657.5$ & $2,259.4$ & $\mathrm{~ns}$
\end{tabular}

Table IV. Changes is Mean CBF, HR, Mean AP, TTI, TTI/CBF Ratio and $\mathrm{PcsO}_{2}$ Obtained in Group A, Group B and Group C 3 min. after the Injection of Coronary Vasodilators

\begin{tabular}{|c|c|c|c|c|c|c|c|c|c|}
\hline & \multicolumn{3}{|c|}{ A } & \multicolumn{3}{|c|}{ B } & \multicolumn{3}{|c|}{$\mathrm{C}$} \\
\hline & Control & After & $\mathrm{P}$ & Control & After & $\mathrm{P}$ & Control & After & $\mathbf{P}$ \\
\hline $\begin{array}{l}\text { Mean CBF } \\
\text { (ml./min.) }\end{array}$ & 96.5 & 111.0 & nes & 45.8 & 46.3 & $\mathrm{~ns}$ & 62.3 & 89.1 & $<0.01$ \\
\hline $\begin{array}{l}\text { HR } \\
\text { (beats/min.) }\end{array}$ & 162.0 & 167.0 & ns & 144.0 & 148.8 & $\mathrm{~ns}$ & 156.6 & 165.3 & ns \\
\hline $\begin{array}{l}\text { Mean AP } \\
\text { (mm.Hg) }\end{array}$ & 97.0 & 100.5 & $\mathrm{~ns}$ & 95.6 & 93.7 & $\mathrm{~ns}$ & 113.5 & 101.4 & $<0.05$ \\
\hline $\begin{array}{l}\text { TTI } \\
(\mathrm{mrr} \cdot \mathrm{Hg} \cdot \mathrm{sec} .)\end{array}$ & $3,090.0$ & $3,150.0$ & ns & $2,391.6$ & $2,252.0$ & ns & $2,656.9$ & $2,635.8$ & ns \\
\hline $\mathrm{TTI} / \mathrm{CBF}$ & 30.9 & 27.6 & $\mathrm{~ns}$ & 23.9 & 23.8 & ns & 26.6 & 18.1 & $<0.01$ \\
\hline $\begin{array}{l}\mathrm{PcsO}_{2} \\
(\mathrm{~mm} \cdot \mathrm{Hg})\end{array}$ & 11.8 & 12.8 & $n s$ & 27.3 & 27.7 & ns & 22.4 & 22.6 & ns \\
\hline
\end{tabular}

If coronary vasodilation was going to be estimated from the EDCVR, some coronary vasodilator increased $\mathrm{CBF}$ (group $\mathrm{C}$ ) and the other did not (group B). In the former group, TTI/CBF ratio decreased, though $\mathrm{Pcs}_{2}$ was not raised.

\section{Discussion}

Coronary vascular bed is narrowed by extravascular compression due to myocardial contraction in systole resulting in decrease in CBF. ${ }^{11}$ Kirk and 
Honig ${ }^{12,13)}$ (1964) showed that extravascular compression expressed in myocardial tissue pressure was not even from layer to layer and therefore blood flow was not equally distributed in myocardium. Furthermore, the hemodynamic changes were considered to produce various form of extravascular compression.

Three different kinds of coronary vasodilator were used for obtaining hemodynamic changes in coronary circulation. Enddiastolic coronary vascular resistance, which was less affected by extravascular compression, ${ }^{7}$ and mean coronary vascular resistance, which was obviously affected by extravascular compression, were compared among them. It was believed to be convenient for further speculation to divide the results, obtained in the series of experiments, into 3 groups: Group A, B and C.

In group $\mathrm{A}$, coronary vascular dilatation did not take place in terms of enddiastolic coronary vascular resistance. However, the fact that mean coronary vascular resistance decreased, showed characteristic feature in hemodynamic change in systolc. No speculation could be given on the data obtained $3 \mathrm{~min}$. after injection of coronary vasodilator, because it was only 1 case (Table II).

In group B coronary vascular dilatation was obvious also in terms of enddiastolic coronary vascular resistance. However, mean coronary vascular resistance remained unchanged as well as other hemodynamic changes (Table III and IV). It suggested that these phenomena on coronary circulation could not be detected without making analysis of pulsatile coronary flow. It was possibly speculated that the reason why mean coronary vascular resistance remained unchanged despite decreased enddiastolic coronary vascular resistance chiefly depended upon increased systolic coronary vascular resistance. Griggs $^{81}$ (1967) recognized decrease of systolic coronary flow after the injection of NTG. Also in this series of experiments, group B was occupied in majority by NTG and TED group. The fact-as Denison") (1956) showed-that adrenergic drugs decreased coronary blood flow in systole was thought to indicate that extravascular compression played an important role in systolic coronary blood flow. Further detailed experiments were thought to be necessary to investigate the relationship between systolic coronary vascular resistance changed by NTG and TED and extravascular compression.

Characteristic feature of group $\mathrm{C}$ was significant decrease in TTI/CBF ratio. However, myocardial oxygen consumption was said to be influenced by TTI ${ }^{87}$ ventricular diameter, thickness of ventricular wall, velocity of contraction of heart muscle and so on. ${ }^{14-16)}$ In this study TTI was used as an index of myocardial oxygen consumption against some opinions. ${ }^{16)}$ Besides this, coronary flow measured here might not be completely representative of actual 
blood supply to the heart muscle. ${ }^{17)}$ In this sense, TTI/CBF ratio remained some space for suspicion when it was used as an index of demand and supply ratio of oxygen to the myocardium.

Most of cases in DIP group belonged to group C. Moir and Debra ${ }^{18 \text { ? }}$ (1967) showed changes in intramyocardial coronary blood distribution induced by $\mathrm{DIP}$ using $\mathrm{Rb}^{86}$. Blood flow distribution was found larger in inner layer than that in outer layer of myocardium. It was naturally thought that increase in blood flow distribution in inner layer, where tissue pressure in systole was higher than that in outer layer, ${ }^{121,13)}$ resulted in decreased systolic coronary blond flow. However, data obtained in this study did not agree with them in this point. Most of the cases in DIP group belonged to group C and they showed marked and prolonged increase in $\mathrm{CBF}$ and increase in $\mathrm{PcsO}_{2}$ (Table IV). Thus increase in $\mathrm{PcsO}_{2}$ was said to be characteristic in DIP group other than group $\mathrm{C}$.

\section{REFERENCES}

1. Melville, K. I. and Lu, F. C. : J. Pharm. Exp. Therap. 99: 286, 1950.

2. Kadatz, R.: Arzneim. Forsch. 9: 39, 1959.

3. Brachfeld, N,, Bozer, J., and Gorlin, R.: Circulation 19:679, 1959.

4. Gorlin, R., Brachfeld, N., MacLeod, C., and Bopp, P.: Girculation 19: 705, 1959.

5. Maxwell, G. M., Crumpton, C. W., Lowe, G. G., White, D. H., Jr., and Castillo, C. A.: J. Lab. Clin. Med. 54: 88, 1959.

6. Wendt, V.E., Sundermyer, J. F., Den Becker, P. B., and Bing, R. J.: Am. J. Cardiol. 9: $449,1962$.

7. Denison, A. B., Bardhanabaedya, S., and Green, H. D.: Circulat. Res. 4: 653, 1956.

8. Griggs, D. M., Jr., Nakamura, Y., and Leunissen, R. L. A.: Fed. Proc. 26: 460, 1967.

9. Gregg, D. E.: Girculation 27 : $1128,1963$.

10. Sarnoff, S. J., Braunwald, E., Welch, G. H., Jr., Case, R. B., Stainsby, W. N., and Macruz, R.: Am. J. Physiol. 192: 148, 1958.

11. Sabiston, D. C. and Green, H. D.: Circulation 15: 14, 1957.

12. Kirk, E. S. and Honig, C. R.: Am. J. Physiol. 207: 361, 1964.

13. Kirk, E. S. and Honig, C. R. : Am. J. Physiol. 207: 661, 1964.

14. Rollett, E. L., Yarchar, P. M., Hood, W. B., Jr., and Gorlin, R.: Circulat. Res. 17: 499, 1965.

15. Sonnenblick, E. H., Ross, J., Jr., Covell, J. W., Kaiser, G. A., and Braunwald, E.: Am. J. Physiol. 209: 919, 1965.

16. Sonnenblick, E. H., Ross, J., Jr., and Braunwald, E.: Am. J. Cardiol. 22 : 328, 1968.

17. James, T. N.: Circulation 32: 10201965.

18. Moir, T. W. and DeBra, D. W.: Circulat. Res. 21: 65, 1967. 